\title{
Propagation and Production of Seacoast Marshelder ${ }^{1}$
}

\section{Mack Thetford and Debbie Miller ${ }^{2}$}

\section{Seacoast marshelder (Iva imbricata Walter} [Asteraceae]), occurs on coastal dunes throughout the south Atlantic and Gulf region (coastal Virginia to coastal Texas) and is used for dune restoration and stabilization projects (Figure 1). The plant has sparse, woody, upright stems reaching heights of 0.3 to $1.2 \mathrm{~m}$ (0.98 to $3.94 \mathrm{ft})$. Leaves are fleshy, narrow and lance-shaped and arrangement may be alternate or opposite. Flowers are not very showy, occur on terminal racemes with a bract below each flower, and have small lavender petals. The flowers appear in late summer and continue into early fall. The plant is prized for its ability to accumulate sand, thereby producing low, rounded dunes (Craig 1991).

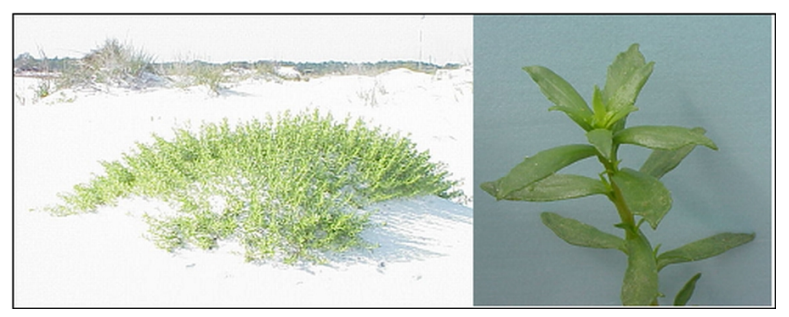

Figure 1. Seacoast marshelder (Iva imbricata) spring foliage detail and entire plant growing in a fore-dune position. Credits: Photo by Mack Thetford.

Softwood cuttings may be prepared from the uppermost 4 inches of non-branched terminal shoots.
Shoots below the 4-inch terminals typically contain many short branches. These short shoots, each containing an intact terminal bud, may also be used to prepare additional cuttings as short as 2 inches. Terminal and lateral cuttings should be segregated and lateral cuttings should be further graded based on cutting length. Auxin application is not needed to achieve $80 \%$ rooting of 2 - to 4 -inch cuttings. However, liquid auxin treatment containing IBA (indole_3_butyric acid) at 1000 ppm has been shown to increase rooting percentage for 2-inch lateral cuttings (Thetford and Miller 2002). Increasing the IBA concentration to $5000 \mathrm{ppm}$ does not further improve rooting or root quality above that achieved without auxin application. Cuttings of 4 inches and smaller may be used for propagation, but propagators should segregate cuttings based on size because differences in shoot height will remain between cutting sizes. Additionally, plants from 4-inch cuttings often produce a greater number of lateral branches than plants from smaller cuttings. Given the obvious difference in transplant branching and size, cuttings should be graded based on initial size before rooting. Shorter cuttings do produce acceptable transplants and should be used when cutting material is limited.

1. This document is ENH975, one of a series of the Environmental Horticulture Department, Florida Cooperative Extension Service, Institute of Food and Agricultural Sciences, University of Florida. Original publication date December 2004. Visit the EDIS web site at http://edis.ifas.ufl.edu.

2. Mack Thetford, associate professor; Environmental Horticulture Department, Deborah "Debbie" L. Miller, associate professor, Wildlife Ecology and Conservation Department, Cooperative Extension Service, Institute of Food and Agricultural Sciences, University of Florida, 5988 Highway 90 , Bldg. 4900, Milton, FL 32583. For more information, contact your county cooperative extension service office.

The Institute of Food and Agricultural Sciences (IFAS) is an Equal Employment Opportunity - Affirmative Action Employer authorized to provide research, educational information and other services only to individuals and institutions that function without regard to race, creed, color, religion, age, disability, sex, sexual orientation, marital status, national origin, political opinions or affiliations. For information on obtaining other extension publications, contact your county Cooperative Extension Service office. Florida Cooperative Extension Service / Institute of Food and Agricultural Sciences / University of Florida / Larry R. Arrington, Interim Dean 
The production schedule for this species in spring and summer months will begin with cuttings stuck in a pinebark-based substrate such as $100 \%$ milled pine bark or a commercial planting mix. Many commercial growers will use 72-cell trays with roots initiating within 2 to 3 weeks. Rooted cuttings are removed from the mist on week 3 or 4 and the plants remain in the propagation flats through weeks 5 to 6 . Plants are irrigated as needed 2 to 3 times each week. Nutritional status of the plants is maintained by liquid fertilization (1 to 2 times each week) with a $150 \mathrm{ppm}$ $\mathrm{N}$ solution from products such as Peters $20 \mathrm{~N}: 10$ $\mathrm{P}_{2} \mathrm{O}_{5}: 20 \mathrm{~K}_{2} \mathrm{O}$ (JR Peters, Inc, Allentown, PA 18106). Seacoast marshelder may be pruned in weeks 4 or 5 before transplant or within 1 week after transplant to initiate branching. Following transplant into 4 -inch or 1-quart pots, plants require an additional 4- to 6-week production period to achieve a full rootball and a canopy of approximately 6 to 8 inches.

\section{References}

Craig, RM. 1991. "Plants for Coastal Dunes of the Gulf and South Atlantic Coasts and Puerto Rico." United States Department of Agriculture Soil Conservation Service Agriculture Information Bulletin 460. 41 pages.

Thetford, Mack and Debbie Miller. 2002. "Propagation of 4 Florida Coastal Dune Species." Native Plants Journal. Vol.3(2):112-120. 